ART. XXXIX.-Review of DeCandolle's Origin of Cultivated Plants; with Annotations upon certain American Species; by Asa Gray and J. Hammond Trumbull.

\title{
PakT II.
}

THE fourth chapter of "L' Origine des Plantes Cultivées" relates to plants cultivated for their fruits; the filth to those cultivated for their seeds. Our present annotations concern a few species or forms of Cucurbitacece, the history of which has been involved in some obscurity and confusion.

A word, in passing, upon the Peach, upon the history of which this volume throws some new light. DeCandolle had formerly suggested China as its home, and he has brought together additional evidence in favor of that view. He shows how this conclusion goes against an old idea that the Peach is a derivative of the Almond, which is indigenous to western Asia, and was unknown to the Chinese anterior to the Christian era, while they had peaches of various sorts long before. Upon Pyrus, there is a note relating to botanical orthography, p. 183, which we append, as it has an application to a few other words. *

Lagenaria vulgaris. Bottle Gourd.-Although doubtless an Old-World plant (DeCandolle attributes it to India, Molucca, Abysinia), yet it is not quite eertain that it had not reached the New World before Columbus. At least the following notes may be put upon record.

M. DeCandolle mentions the case of the name gourd for pumpkin ("potiron") by English writers, as "an example of the confusion of popular names and the greater precision of scientific names." Such confusion becomes more perplexing when we have to deal with popular names of the 15th and 16th centuries. Parkinson-a good observer and a respectable botanist-complained, in 1640, of "our modern writers who confound Pepo, Melopepo and Cucurbita, so promiscuously that it is not possible to find out the distinct certaintie of them all; for some make that Pepo that others call Melopepo, and ocher's, Cucurbita." (Theater of Plants, p. 770.) Scientific names of the 16 th century are as obsolete as popular names of the same period. They do not help us to distingush Lagenaria from Cucurbita, or Pepo from Melopepo; or "Citrouille" from Citrul-

* "L'Orthographe Pyrus, adopté par Linné, se trouve dans Pline. Historia, ed. 1631, p. 301. Quelques botanistes ont voulu raffiner en écrivant Pirus, et il on result, pour une recherche dans un livre moderne, il faut consulter l'index dans deux endroits, ou risquer de croire que les Poiriers ne sont pas dans l'ouvrage. En tous cas le nom des anciens est un nom vulgaire, mais le nom vraiment botanique est celui de Linné, fondateur de la nomenclature adoptée, et Linné a ecrit Pyrus."

Pears and Apples were prehistoric in Europe, both wild and cultivated. 
lus. Early voyagers to America wrote cucurbita, calabaça, courge or zucca, as a name for any 'gourd' or pumpkin, and occasionally for a 'calabash' which was not even a cucurbit. The relation of the first voyage of Columbus repeatedly men. tions the calabazas used by the natives of St. Domingo and other islands for carrying water (Navarrete, Collec. i, 180, 188), and, Dec. 3, 1492, Columbus saw, near the east end of Cuba, fields planted with calabazas and other productions of the country (id. p. 225). Yet we know from Peter Martyr that some of the gourds ("cucurbitæ") used in the islands grew on "cucurbiteas arbores" as tall as elms (Dec. i. lib. 3, and iii, lib. 4 ; pp. 38, 246). This tree, Crescentia crijete, is described by Oviedo (Hist. gén., lib. viii, c. 4) under its Haytian name, Higuëro; in Nicaragua, it was called Guacal; and in Brazil, Cuiele* (Marcgrav, Hist. Nat. Brasil., 123). J. de Lery (Hist. Navig. in Brastl., 154) describes the tree under the Brazilian name of Choyne; but elsewhere (p. 246) he says "the natives have cucurbilice (courges) and other kinds of fruits," from which "they make their bowls, called coui, and other vessels."

It is certain that calabaças which were not arboreal, but genuine cucurbits, were abundant-and were believed to grow spontaneously - in the islands and on the main land, before 1526. Oviedo (Hist. gen. y vat., lib. vii, c. 8) observes that "calabaças, in the Indias, were as common as in Spain, and of the same kinds (de las mismas), long and round, or banded (çeñidas), and of all the shapes they usually have [in Spain]." They were much used, "in all parts of these Indias, both the Islands and the Main," and "are one of the common things that the Indians cultivate in their gardens." They were not cultivated for food-" for they do not eat them "- but for carrying water; "and they have other calabacas, that are in all respects like the aforesaid, except that they are bitter to the taste; and there are many of these that grow of themselves, without cultivation." $\nmid$ The same author (lib. xi, e. 1) in a list of plants introduced from Spain, names melons and cucumbers (pepinos), but not gourds.

The relation of the voyage of Amerigo Vespucci, 1489, in a description of the Indians of Trinidad and the coast of Parria. says that "each carried, hanging at his neck, two small dried gourds (cucurbitas), one containing the plant that they were accustomed to chew, the other, a certain whitish flour," etc.,

* Not Cujete-uuless $j$ has the German sound. The Tupi name is formed from cü̈ (ccu-in, Lery) ' the shell' or hard rind of a nut or fruit (and the 'bowl' or calabash made from it) and eté 'good, precious.'

+ M. DeCandolle, p. 198, citing this passage from Ramusio's Italian translation of Oviedo's Historia Natural, etc., has "zucche" for "calabaças" of the Spanish original, and takes no notice of what is said of their spontaneous growth. 
and that each woman carried a cucurbita of water (Navarrete, iii, 252, 254).

The "Cucurbita lagenæ formâ," which Marcgrav found in Brazil, 1637-8 (Hist. Nat. Brasilice, 44), though "very probably Lagenaria vulgaris," yet, as M. DeCandolle observes, "does not prove that the species was in that country before the voyage of Anerigo Vespucci in 1504 ;" but we know from Lery, above cited, that the natives of Brazil used cucurlitoe, for bowls and drinking vessels, at least as early as 1557 . Moreover, the richness of the Tupi vocabulary in gourd-names suggests-if it does not absolutely prove - that several varieties of Lagenaria were known to the Brazilians long before the visit of Piso and Marc. glav. The Tesoro de la Lengua Guarani (o Tupi) of Father Ruiz de Montoya was first printed in 1639 . It gives for gourd (calabaço), the Tupi general name, $I a$ [which is a compound of $u$ 'water,' and ya or $a$ 'fruit'], and for' the varietiesamong others-it names zaç̌̀ ' round gourd;' ̌áyurumî ' narrow-mouthed gourd;' záť 'long-necked gourd;' záobáa 'widemoutbed gourd;' ̌́áquatiâ 'painted gourā; ǔácuêpé 'spoon gourd' (used for making spoons); $\breve{a} a$ apê 'small gourd, used for'

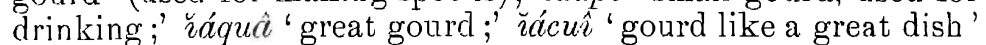
or bowl, etc.: not including the derivatives of cûे, or the edible "calabaças" - to be mentioned hereafter.

"Acosta, too," says M. DeCandolle, "speaks of Calebasses which the Peruvians used for cups or vases, but the Spanish edition of his book is of 1591 , more than a hundred years after the conquest." (?) Acosta says more than this. After mention of the "Calebasses or Indian Pompions . . . especially those which are proper to the country" [Peru], he adds: "There are a thousand kinds of Calebasses; some are so deformed in their bigness that of the rind cut in the midst and cleansed, they make, as it were, baskets to put in all their meat, for their dinner. Of the lesser, they make vessels to eat and drink in," etc. (Hist. nat. y moral ḋe las Indias; translation, revised by Murtcham, lib. iv, c. 19 ; p. 238).

Cucurbita maxima, C. Pepo, C. moschata. Pumpkin, Squash, etc.In the Géographie Botanique not one of the ciltivated Cucurbitce. is attributed to America, and a reference to Nuttall's record that the warted squash was grown by the Indians on the upper Missouri is the only mention of any aboriginal cultivation of squashes in North America. In the present volurne, there is merely a reference, in this respect, to Dr. Harris's article in this Journal (xxiv, 1857), and to Mr. Trumbull's note in the Bulletin of the Torrey Club (1876), with the comment that: "Cela nous apprend seulement que les indigènes, un siècle après la découverte de la Virginie, 20 à 40 ans après la colonisation par W. Raleigh, faisaient usage de certains fruit de Cucurbitacées." 
Nevertheless Cucurbita Pepo, upon botanical indications solely, is attributed to temperate North America in the general table, to a Mexican or Texan origin in the body of the work. This rests upon the collection by Lindheimer, in Texas, of a form of this species, "apparently indigenous." That was between thirty and forty years ago: no wild specimen has since been received from all that region (nor from any other); and it is well nigh certain that the species was commonly cultivated in all that country by the aborigines. If ever found truly indi. genous, it will probably be farther south than Texas. C. maxima is now set down as from Guinea, on the strength of a single finding of it "apparently indigenous" on the banks of the Niger. C. moschata (to which Vilmorin refers the Canada crook-neck Squash) is in the list of species of completely unknown or uncertain origin.

In this state of the case, it is certainly worth while to present the evidence-gathered with much care and pains-which assures us that one or two, and perhaps all three, of these species, and many varieties, were largely cultivated throughout America, from the tropics to Canada, before the voyages of Columbus.

Allusion bas already been made (under Lagenaria) to the difficulty of distinguishing the genera of Cucurbitacece, under the names by which they are mentioned by voyagers and explorers of the first century after the discovery of America; and the question of species is particularly difficult. Yet we find abundant evidence-especially as respects North America-(1) that, in various parts of the country, remote from each other, the cultivation of one or more species of Cucurbits by the Indians was established before those places are known to have been visited by Europeans; (2) that these species or varieties were novel to Europeans, and were regarded by botanists of the 16th and 17 th centuries, as well as by the voyagers and first colonists, as natives or denizens of the region in which they were found; and (3) that they became known only under American names: one of these names (Squash) becoming, in popular use, generic, and two olhers (Macock and Cushaw) surviving, as names of varieties, into the present century.

To present this evidence, as nearly as possible in the order of time, we refer, first, to the relation of the first voyage of Columbus. Dec. 3, 1492, entering a small river [the Rio Boma], near the eastern end of the island of Cuba, he found near it a populous Indiar village and saw large sultivated fields "planted with many things of the country, and calabazas, a glorious sight (que era gloria vella)!" See Navarrete, Colec., i, 225. It is not certain that these calabazas were not bottlegourds (Lagenaria), but it is, to say the least, highly improb. 
able, that the enthusiasm of Columbus would have been so kindled by the promise of a harvest of little value to Europeans.

Oviedo (Hist. gen. y nat., l. xi, c. l) names among plants and seeds brought from Spain to Hispaniola, "melones" and "pepinos" - of which imported varieties were already abundant in the island before 1535 ; the seed of "cogombros" brought from Castile had not succeeded so well.

In July, 1528, Cabeça de Vaca found, near Tampa Bay, in Florida, "maize, beans and pumpkins in great plenty, and beginning to be fit for gathering." In 1535-6, when passing through Texas, the Indians supplied him with prickly pears and, occasionally, maize; but after crossing "a great river coming from the north "-probably the Rio Grande-he and his companions came to a region having "fine dwellings of" civilization, whose inhabitants lived on beans and pumpkins"and, when the season was not too dry for raising it, maize (Relacion, 1542 ; transl. by B. Smith, 1871).

In the summer and autumu of 1539, De Soto found the Appalachian country, in western Florida, well supplied with "maize, beans (fésules) and pumpkins (calabaças);" the pumpkins of Uzachil were "better and more savoury than those cf Spain;" there were "fields of maize, beans and pumpkins," not far from Tampa Bay, where he first landed from Cuba; at Pacaha, on the Mississippi the northernmost point he reached (154l), he found, again, "many pumpkins and much maize and beans;" and, still westward, at Coligoa, "beans and pumpkins were in great plenty; both were larger and better than those of Spain; the pumplins when roasted had nearly the taste of chestnuts" (Oviedo, lib. xvii, cc. 24, 28; True Relation, etc., by a Fidalgo of Elvas; transl. by Buckingham Smith, pp. 45, 47, $122,285)$. Oviedo writes "calabaças," but the author of the Portuguese Relacam Verdadeira (1557) has, in one or more of tbe places cited, "aboboras."

In 1535, Jacques Cartier, the first explorer of the St. Lawrence, found among the Indians of Canada "grand quantite de gros melons, concombres and courges" (Bref Recit de la Navigation, etc., 1545; reimpr. Tross, 1863, ff. 24, 31).

Sagard, whose Grand Vuyage du Pays des Hurons was made in 1642 , makes repeated mention of the native squashes ("citrouilles du pays"), which the Hurons raised in abundance, and which he found very good, boiled or baked (pp. 85, 105, 140, 331). In his Histoire du Canada (283), he describes the method by which the Indians hastened the germination of the seeds of these "citrouilles du pays," and "raise them with great ease."

Lahontan (Nouv. Voyages, 1703, ii, 6l) describes the Citrouilles of (southern) Canada- "sweet, and of a different kind from 
those of Europe, where," as several persons assured him, these would not grow. "They are of the size of our rnelons; the flesh, yellow as saffron. They usually bake them in the oven, but they are hetter roasted under the embers, Indian fashion," etc. Lahontan had as little doubt as Sagard had, that these citrouilles (cultivated by the Indians of Canada from the time of Cartier, at least) were genuinely "du pays."

As to the Cucurbitaceæ of Virginia, M. DeCandolle admits, "only, that the natives, a century after the discovery of Virginia, twenty to forty years after the colonization by W. Raleigh, made use of certain fruits of Cucurbilacece" (p. 201). Let us reëxamine the evidence. Captains Amidas and Barlow, in the first vessels sent by Sir Walter Raleigh to the New World, landed on an island in Ocracoke Inlet (now within North Carolina) in 1584. While the vessels remained there, and while they were at Roanake Island near by, the Indians entertained them kindly, and "sent them, commonly every day, a brace of bucks, conies, etc., sometimes Melons, Walnuts, Cucumbers, Pease, and divers roots" (J. Smith's Gen. History, p. 3).

What these "melons," or some of them, were, we learn from later explorers and the first colonists of Virginia (proper).

Capt. John Smith says that the Indians of Virginia (1606-08) "plant amongst their corn Pumpions, and a fruit like unto a musk-melon, but less and worse, which they call Macocks," etc. ( ( describes these "macock gourds" in nearly the same words (Trav. into Virg., p. 72) ; elsewhere, he says the "macokos is of the form of our pumpions-I must, confess, nothing so good,'tis of a more waterish taste," and he mentions also, the "pumpions" planted by the Indians, and "a kind of million" which they "seeth, and put into their walnut-milk, and so make a kind of toothsome meat" (p. 119). "The Irdian Pumpion, the water-melon, musk-melon," etc., are named arnong fruits introduced into Bermuda, by the English, before 1623 (Smith's Gen. Hist., 171).*

Among Johnson's additions to Gerarde's Herball, 1636, there

* L'Ecluse (Clusius) heard of these Macocks in 1591, or earlier. In his Exotica (1605 ; lib. iii, c. 2 ) he describes a fruit-" Macocqwer Virginlansium, forte"-which had been sent him from London by James Garet, brought from "the province of Wingandecaow, which the English call Virginia." He conjectured that this might be "the fruit which the natives of that region call Macocqwer"-but his figure and description do not favor this identification. The fruit, he says, is nearly orbicular; four inches in diameter; with a liard rind, yellowish on the outside; many seeds, flat and heart-shaped ("cordis, ut vuigo pingitur, formam referentia"). L'Wcluse thought it might be one of the gourds which the natives used for rattles, as the Brazilians used their Tamaraca, etc. His specimen was old and dried, the pulp blackened, the rind covered with a dark membrane, "per quam sparsæ quædam fibræ à pediculo ad summum." This must have been a fruit of Crescentia cucurbiitina, a calabash, which is a native not only of West Indies, but also of Southern Florida. 
is a description of "Macocks Virginiani, sive Pepo Virginianus; the Virginian Macock or Pompion" (pp. 919, 921). The description is dated, 1621, and signed by John Goodyer. The plant has "great broad shrivelled yellow flowers, like those of the common Pompion." The fruit, "somewhat round, not extending in length, but flat like a bowl, but not so big as an ordinary bowl, being seldom four inches broad and three inches long; of a blackish green color when it is ripe. The substance or eatable part, of a yellowish white color. . . . "Seeds like the common Pompion, but smaller." The "small round Indian Pompion," and "the cornered Indian Pompion"-the latter" resembling our common "scolloped Squash" ("Pepones lati, Broad Melons or Pepons" of Lyte's Dodoens, p. 588) are described and figured in Johnson's Gerarde, p. 920.

Beverley's History of Virginia, 1705, p. 124, mentions the Macocks, "a sort of Melopepones, or lesser" sort of Pompion or Cashaw," which he identifies with the "Squash or Squonter Squash" of New England. "The Indian name," he says, "is still retained by them." Professor Schele de Vere (of Virginia). states that it still "survives in its anglicized form of Maycock" (Americanisms, 1871 ; p. 60).

The Cushaw (Ecushaw, Hariot) is described by Beverly (Hist. of Virg., p. 124) as "a kind of Pumpion, of a blueish green color, streaked with white when they are fit for use. They are larger than the Pompions, and have a long narrow neck. . . . The Cushaws and Pompions they lay by, which will keep several months good, after they are gathered" (p. 152). Bartlett, Dict. of Americunisms, notes the name Cushaw, "sometimes spelled Kershaw," as "Western" for a pumpkin. Beverley's description makes it nearly certain that the variety so named was the (New England) winter "crool-neck" squash-which, five and twenty years ago, might have been seen hanging, by its necklace of "flannel "list," in every New England's farmer's kitchen, from early harvest time till wanted for Thanksgiving or Christmas pumpkin-pies.

The Rev. Francis Higginson, who came to New England in 1629, wrote from Salem, a few weeks after his arrival: "Here are stores of pompions, cowcumbers, and other things of that nature which I know not" (N. E. Plantation, 1630); and, again, "We abound with . . . sundry sorts of fruits, as musk-melons, water-melons, Indian pompions, Indian pease, beans, and many other odd fruits that I cannot name" (Young's Chron. of Mass., 265̃). William Wood, who was in New England from 1629 to 1633 , says, of the Indians of Massachusetts: "In summer, when their corne is spent, Isquoutersquashes is their best bread, a fruit like a young Pumpion" N. E. Prospect, p. 76). Roger Williams, 1643, names these "Askútasquash, their vine apples, 
which the English from them call Squashes, about the bignesse of apples, of several colours, a sweet, light, wholesome refreshing" (Key to the Language of America, 103). Again, Josselyn (1638-71, N. E. Rarities, 57) mentions these "Squashes . . . more truly, Squontersquashes, a kind of melon or rather gourd, for they oftentimes degenerate into gourds; some of these are green, some yellow, some longish like a gourd, others round like an apple, all of them pleasant food boiled and buttered, etc. But the best yellow Squash, called an Apple Squash, because like an apple, and about the bigness of a Pome-water, is the best kind: they are much eaten by the Indians and the English." But he distinguishes these from the "Pompions [of which] there be several kinds, some proper to the couritry; they are dryer than our English Pompions, and better tasted; you may eat them green" (p. 91). The last words (here italicized) give a nearly literal trauslation of the Algonkin-Indian name of Cucurbits,in the dialect of New England, asq, plural asquash, 'green things,' or (to be eaten) 'immature.' Eliot, in his version of the Bible (1663) names three kind of asquash: askoot-asquash, [=Askitasquash R. Williams, Isquoutersquash-es of Wood, Squontersquash-es of Josselyn, ut supra,] for "cucumbers;" quonoo-asquash "gourds" [literally, "long asquash?]; and monaskoot-asquash "melons."

"Squashes" were first known to the Dutch, by their Algonkin name. Van der Donck, after speaking of the pumplins of New Netherland (1642-53) adds: "The natives have another species of this vegetable peculiar to themselves, called by our people quaasiens, a name derived from the aborigines, as the plant was not known to us before our intercourse with them. It is a delightful fruit, as well to the eye on account of its fine variety of colours, as to the mouth for its agreeable taste. . . . It is gathered early in summer, and when it is planted in the middle of April, the fruit is fit for eating by the first of June. They do not wait for it to ripen before making use of the fruit, but only until it has attained a certain size. They gather the squashes and immediately place them on the fire without any further trouble. . . The natives makes great account of this vegetable." Descript. of $N$. Netherlands, 1656 ; transl. in $N . Y$. Hist. Soc. Coll., 2 Ser., i, 186.

Thus far, we have cited, with one or two exceptions, American authorities. M. DeCandolle, after mentioning "the three forms of Pepones figured by Dodoens, edition of 1557 , to which a fourth, $P$. rotundus major was added in the edition of 1616 ," ard a figure of $P$.oblongus, in Lobel. Icones, 641 , observes, that "the names given to these plants indicate a foreign origin; but, the author's can affirm nothing, in this regard; the less so, because the name Indian signifies, either, of southern Asia or of 
America" (p. 204). A collation of the descriptions of "Pepones" or "Cucurbitæ," given by European botanists of the $16 \mathrm{th}$ century, does away with this ambiguity.

Tragus (Hieron. Bock) De Stirpium Nomenclaturis, etc., 1552, p. 830, described and figured "Melo, Pepo, Cucumis, and Citreolus ;" and (p. 832) named, also, Cucumis sylvestris. In the next chapter (p. 834) be wrote "De Cucumere seu, ut vulgo loquuntur, Zucco marino" — with a figure. "Many kinds of strange plants," he says, "have been brought from remote parts, into Germany, in the last few years." Among others, these "poma aestiva," of which some are large, some small, some round, some oblong, some sweet, others bitter, of various colors. "Some call these Cucumeri, and assert that they are Turkish Cucumeres, with which opinion I cannot agree. ... I call them Mala cestiva $\&$ Indica," of which be distinguishes four kinds, $M$. Indica crocea, lutea, citrina, and nigra. "Commonly," he says, "they are called Zucco marina, because they first came to us from parts beyond the sea, some from Syria, some from India, which the names given them attest; for they are commonly called, Zucco de Syria and Zucco de Peru."

The figure of "Cucumer marinus, Ital. Cocomere marino," etc., in the Effigies Plantarum of Fuchs, 1549, is a reduced copy of Bock's, and substantially agrees with that of Pepo rotundus in Lyte's Dodoens, p. 587, which was "called, also Cucumis marinus; of some, Zucco marino; in French Concombre marin, Pompons Turquins," etc.

Matthioli, of Padua (Comm. in Dioscor., ed. 1559, p. 292) is more explicit. "There are," he says, "various kinds of cucurbits foreign to Italy, which can be kept fresh far in to the winter. They say that these carne into Italy from the West Indies, whence they are called by many Indian. Their taste is sweetish, not so insipid as ours," etc. ; and his figure of "Cucurbita Indica" agrees with that of Bock's Zucco marinus (or "Zucco de Peru") and with Lyte's Pepo rotundus.

It is certain, then, that the botanists of the 16th century to whom M. DeCandolle refers, used Indian-when applied to varieties of Cucurbita-in the sense of American. In the 17 th century, the evidence is not less direct. Parkinson (Theatrum Botanicum, 1640, pp. 769, 770) figures and describes (1) " $\mathrm{C} u$ curbuta lagenaria major, the greater Bottle Gourd ;" (2) "C. longa, the long Gourd;" $(3,4)$ "C. clypeiformis \& verrucosa, and Anguria Aegyptiaca, the Simmel [Scallop Squash], and the rugged Gourd [warted Squash, orbiculate depressed], and the Egyptian Citruell or Watery Million;" (5) Cucurbita Indica, ovalis, pyriformis, \& fere rotundus, Indian Gourds, oval, pear fashioned, and almost round." Of these "Indian Gourds," he says: "There is very great variety of these Gourds (or Millions, as 
some call them, or Pompions, as I may call them) that came out of America or the West Indies, firom sundry places, both farther south among the Spanish colonies, and nearer hand, in our own of Virginia, New England, etc." He notes the great variety of size, shape and color, "some as great as our pompions, some as small as an apple, some discolored on the outside, green with whitish or yellowish stripes, .. some also reddish, spotted ol' striped, and some of a deep yellow."

Piso and Marcgrav (Hist. nat. Brasilae, 1648, p. 44) describe and figure a plant called Iurumu [= Yurumu $]$ by the Brazilians, and by the Portuguese, Bobora. M. DeCandolle, p. 201, is inclined to agree with modern botanists in referring this to C. maxima; but, as he remarks, it appears to have been a cultivated plant. If introduced trom abroad, the name given it by the Tupis was probably formed, by prefix or aftix, from that of some native (or naturalized) species to which it had some resemblance. In Montoya's Tesoro, 1639, we find Yuruá "calabacillos silvestres," small wild calabazas: but the name Yurumu did not yet appear. Almost a century before the visit of Piso and Marcgrav, Jean de Lery saw in Brazil (1557) "celtains citrouilles rondes, fort douce à manger," called by the natives Maurongaus (Voyage, ed. 1578, p. 217). The Tupi name mo. rangá (the first two vowels nasal) denotes a 'handsome fruit.' 